\title{
New species and collections of Opiliones (Arachnida) from Turkey
}

\author{
Nataly Yu. Snegovaya ${ }^{1} \&$ Yuri M. Marusik ${ }^{2}$ \\ ${ }^{\prime}$ Zoological Institute NAS of Azerbaijan, proezd 1128, kvartal 504, Baku, AZ 1073, Azerbaijan \\ E-mail: snegovaya@yahoo.com \\ ${ }^{2}$ Institute for Biological Problems of the North RAS, Portovaya Str. 18, Magadan 685000, Russia \\ E-mail:yurmar@mail.ru
}

\begin{abstract}
Collections of 22 species of harvestmen are reported from Turkey. Three are new to science: Histricostoma mitovi sp. n., H. gruberi sp. n. and Egaenus turcicus sp. n. Three species, Odiellus zecariensis Mkheidze 1952, Opilio insulae Roewer 1956 and Opilio sp., are reported from Turkey for the first time. Illustrated descriptions are provided for new and poorly known species.
\end{abstract}

Key words - Harvestmen, new species, new record, checklist, fauna

\section{Introduction}

The harvestmen fauna of Turkey is not adequately known. Information about Opiliones from the region is scattered among different faunistic and taxonomic papers. The first species of harvestmen were reported from the country by Kulczyński (1903). He described three new species: Egaenus crista var. anatolicus (currently $=$ Zachaeus a.), Platybunus strigosus olympicus (currently $=$ Rafalskia olympica) and Nemastoma werneri (currently $=$ Paranemastoma werneri). The next paper was by Nosek (1905) and reported six species from Turkey, four of which were described as new: Phalangium kulczynskii (currently = Dasylobus $k$.), Phalangium argaeicum (currently $=$ Dasylobus kulczynskii), Phalangium strandi (currently = Metaphalangium s.) and Egaenus marenzelleri. A very important contribution to the study of Turkish harvestmen was made by Roewer $(1923,1950,1956,1957,1959,1962)$. In his series of papers, Roewer reported or described as new 26 species of Opiliones from Turkey. Another new species, Zachaeus orchimonti, was described by Giltay (1933). Further, 18 species were described or reported from Turkey by Gruber and Šilhavý (Gruber 1963, 1968, 1969, 1976, 1978, 1979, 1998; Šilhavý 1955). Six species of harvestmen were reported by Martens in his survey of the European fauna and revision of Nemastomatidae (Martens 1978, 2006). Currently studies of the Turkish fauna of Opiliones are being conducted by several Turkish arachnologists: A. Bayram, İ. Çorak, N. Yığıt, K. Kurt and others (Çorak 2004; Corak \& Bayram 2007; Bayram \& Çorak 2007; Yığıt et al. 2007; Kurt et. al. 2008a,b, 2010, 2011; Bayram et al. 2010). They reported dozen of species, some of which were new to the fauna of Turkey: Lacinius ephippiatus C. L. Koch 1835, Opilio parietinus (De Geer 1778), Phalangium opilio Linnaeus 1761, Metaplatybunus petrophilus Martens 1965, Oligolophus tridens (C. L. Koch
1836), Oligolophus hanseni (Kraepelin 1896), Odiellus lendli (Soerensen 1894), Homolophus funestus L. Koch 1877, Opilio lederi Roewer 1911, Leiobunum rotundum (Latrielle 1798), L. rupestre (Herbst 1799), Mitopus morio (Fabricius 1779), Nelima pontica Charitonov 1941 and Ischyropsalis helwigii (Panzer 1794). In total 65 species and one subspecies belonging to seven families were known in Turkey (Kurt et. al. 2010, 2011; Kunt \& Y1ldı 2010).

The present paper is largely based upon new specimens of Opiliones that were collected during a Turkish-Russian Arachnological expedition in 2009. A few other specimens are newly reported from the collection of the American Museum of Natural History and one species collected by a Finnish colleague P. T. Lehtinen. Judging from the figures provided in earlier papers and our knowledge about distributions of Palaearctic Opiliones, it is very likely that some of these previous records are based upon misidentifications. Further collections and study are needed.

\section{Material and methods}

Material treated herein is deposited in the Turkish Arachnological Society collection (TASC), in the Zoological Museum of the Moscow State University (ZMMU), Zoological Museum University of Turku (ZMUT), American Museum of Natural History (AMNH), and the reference collection of the first author (RCNS).

All specimens treated here (except for five specimens of Odiellus lendli and a few from the AMNH) were collected during a short Turkish-Russian Arachnological expedition during May 27-June 14, 2009. Eight provinces: Ankara, Bolu, Kastamonu, Bursa, İzmir, Aydın, Antalya and Artvin were visited during the collection trip (Map 1). The specimens were collected by litter sifting with the help of an aspirator and preserved in $70 \%$ ethanol. The main goal of this trip was to collect spiders and Opiliones were collected only sporadically. Specimens were photographed using an 


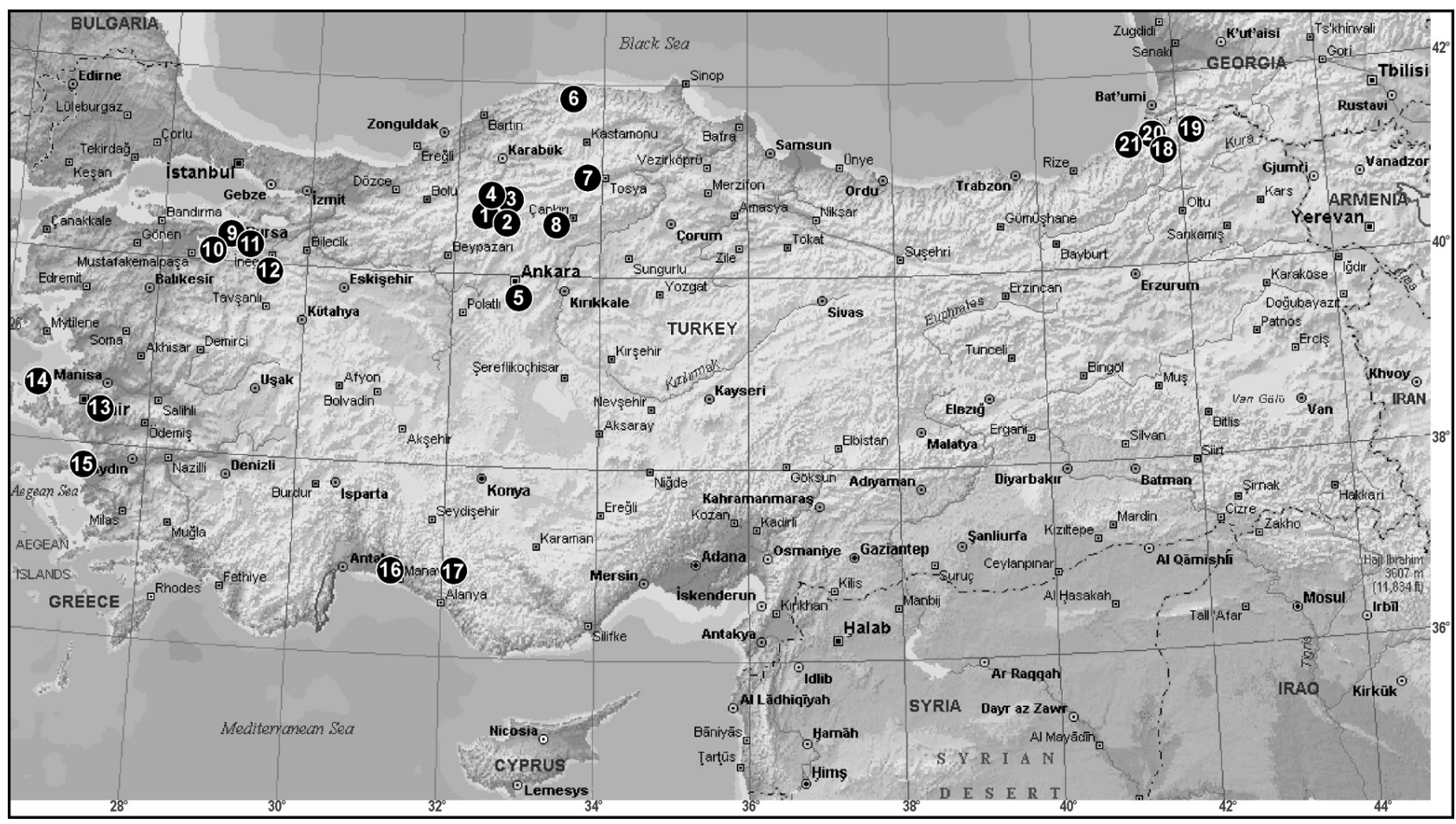

Map 1. Localities studied during Turkish-Russian Arachnological trip in 2009.

Olympus Camedia C-520 camera attached to an Olympus SZX16 stereomicroscope. The images were montaged using "CombineZM" image stacking software. All measurements are in $\mathrm{mm}$. abbreviations: $\mathrm{Fe}=$ femur, $\mathrm{Pa}=$ patella, $\mathrm{Ti}=$ tibia, $\mathrm{Mt}=$ metatarsus, $\mathrm{Ta}=$ Tarsus.

\section{Species survey}

Sironidae Simon 1879

Cyphophthalmus duricorius bithynicus (Gruber 1969)

(Figs. 1-3)

Siro duricorius bithynicus Gruber 1969, p. 75, f. 1-3.

Material examined. 1\% (ZMMU), TURKEY [T-09] Bursa, Uludağ National Park, $40^{\circ} 06.970^{\prime} \mathrm{N} 29^{\circ} 03.283^{\prime} \mathrm{E}$, 648 m, 1 \& 4.06.2009 Yu M. Marusik.

Comments. This subspecies was described and is known so far from only the environs of Bursa. Our specimen came from the type locality.

Trogulidae Sundevall 1833

Platybessobius singularis Roewer 1940

Platybessobius singularis: Martens 1966, p. 348; Gruber 1969, p. 82; Mitov 2003, p. 275.

Material examined. $1 \delta^{\Uparrow}, 1$ juv. (ZMMU), TURKEY [T21/2-3] Artvin Province, Arhavi, $41^{\circ} 22.068^{\prime} \mathrm{N} 41^{\circ} 20.412^{\prime} \mathrm{E}$, $225 \mathrm{~m}, 13.06 .2009 \mathrm{Yu}$ M. Marusik.

Comments. This species was described from Crete.
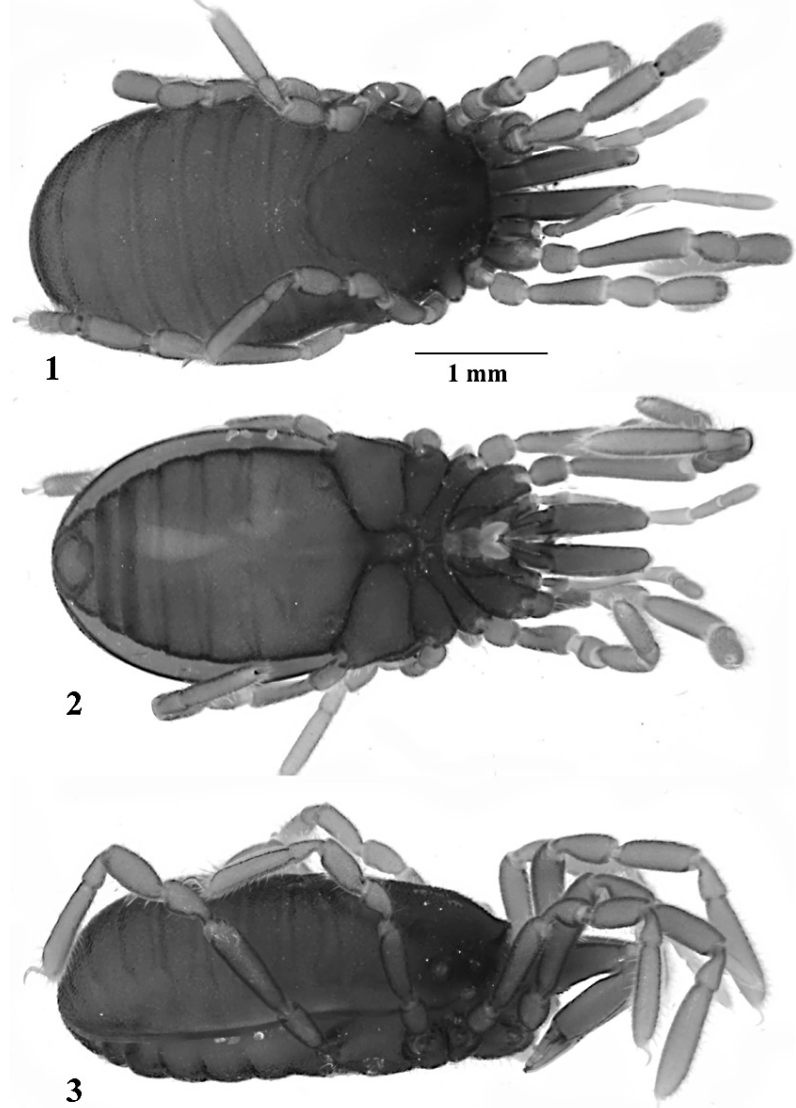

Figs. 1-3. Cyphophthalmus duricorius bithynicus (Gruber 1969), male (Bursa, Uludağ National Park). 1. Body, dorsal view; 2 . Same, ventral view; 3. Same, lateral view. 
Later it was reported from mainland Greece (Chora Fakia) by Martens (1966). Besides these two localities it was found in Turkey (Anatolia) by Gruber (1969).

\section{Dicranolasmatidae Simon 1879 Dicranolasma hoberlandti Šilhavý 1955}

Dicranolasma hoberlandti Šilhavý 1955, p. 32, Tab.1, f. 1-8; Martens 1965, p. 67, f. 2-5; Gruber 1969, p. 86; Staręga 1973, pp. $131-132$, f. $3^{-6}$.

Material examined. $10^{\lambda}, 1$ 우 (ZMMU), TURKEY [T-12] Bursa, İnegöl, Great Oylat Cave, 3956.601'N 29³5.492'E, 519 m, 3.06.2009 Yu. M. Marusik.

Comments. This species has an East Mediterranean range. It was described from Turkey (Suluhan, Taurus). Later it was found in the environs of Bursa (Gruber 1969), in Greece (Rhodos, Martens 1965) and also from Israel (Staręga 1973)

\section{Dicranolasma giljarovi Šilhavý 1966}

Dicranolasma giljarovi Šilhavý 1966, p. 153, f. 14-20; Staręga 1978, p. 4; Chevrizov 1979, p. 9, f. 31-34; Bayram \& Çorak 2007, p. 9, f. 1 A-H; Çorak \& Bayram 2007, p. 457, f. 4-5; Chemeris \& Kovblyuk 2005, p. 306, f. 1-8.

Material examined. 1우 (ZMMU), TURKEY [T-06] Kastamonu, Azdavay, $41^{\circ} 41.938^{\prime} \mathrm{N} 33^{\circ} 25.971^{\prime} \mathrm{E}, 975 \mathrm{~m}$, 30.05.2009 Yu. M. Marusik.

Comments. This species has an East Mediterranean range. It was described from northern Caucasus (Krasnodar Province of Russia) and later was found in Abkhazia (Staręga 1978), Crimea (Çhemeris \& Kovblyuk 2005), Bulgaria (Staręga 1976) and Turkey (Çorak \& Bayram 2007; Bayram \& Çorak 2007 (Ankara, Istanbul, Kirikkale, Van).

\section{Dicranolasma sp.}

Material examined. $1 \delta^{\Uparrow}, 1$ 우, 1 juv. (RCNS), TURKEY [T-01h] Ankara, Kızılcahamam. Soğuksu National Park, Göllü, $40^{\circ} 26.794^{\prime} \mathrm{N} 32^{\circ} 35.476^{\prime} \mathrm{E}, 1608 \mathrm{~m}, 27.05 .2009 \mathrm{Yu}$. M. Marusik; 2๙ㅈ, 1우 (RCNS), [T-02] Ankara, between Kizilcahamam - Ankara roads, $40^{\circ} 21.133^{\prime} \mathrm{N} 32^{\circ} 40.811^{\prime} \mathrm{E}$, 1000 m, 27.05.2009 Yu. M. Marusik.

Comments. Six species of Dicranolasma are known to occur in Turkey: D. hoberlandti Šilhavý 1955, D. giljarovi Šilhavý 1966, D. scabrum (Herbst 1799), D. ponticum Gruber 1998, D. ressli Gruber 1998 and D. soerenseni Thorell 1876. Our specimens are most similar to $D$. giljarovi and $D$. ressli. At this moment we can not identify them to species level because of lack of comparative material.
Nemastomatidae Simon 1872

Pyza taurica Gruber 1979

Pyza taurica Gruber 1979, p. 566, f. 4, 8, 13, 18.

Material examined. $2 \delta^{\pi} \delta^{\pi}$, 4 우우, 1 juv., TURKEY [T17b] Antalya, Alanya, Taşatan Plateau, $36^{\circ} 40.521^{\prime} \mathrm{N} 32^{\circ}$ 10.998'E, 1290 m, 9.06.2009 Yu. M. Marusik.

Comments. This species was described from southern Turkey and known so far only south of the Taurus mountains (Isparta, Burdur, Antalya, Mersin and Niğde Provinces). The species name is derived from the Taurus mountains, but not from Tauri nor Tauria (=Crimean Peninsula).

\section{Paranemastoma superbum Redikorzev 1936}

Paranemastoma superbum Redikorzev 1936, p. 40, f. 11-14; Mcheidze 1959, p. 111; Martens 2006, p. 200, f. 29a-f, 30e-f. Nemastoma supersum: Staręga 1966, p. 392; Staręga 1978, p. 206.

Material examined. $2 \widehat{\jmath} \widehat{\delta}, 1$ 우, 1 juv. (ZMMU), $1 \delta^{\lambda}$ (RCNS), TURKEY [T-21/2-3] Artvin, Arhavi, $41^{\circ} 22.068^{\prime} \mathrm{N}$ $41^{\circ} 20.412^{\prime} \mathrm{E}, 225 \mathrm{~m}, 13.06 .2009$ Yu. M. Marusik.

Comments. This species has an east Mediterranean range. It was described from Ajaria (SE Georgia) an area which is adjacent to Artvin Province. Later it was reported from different parts of Georgia (Mcheidze 1959, 1964; Staręga 1966; Martens 2006) and in two localities in Turkey (Martens 2006: East Pontus Mountains and Kaçkar Mountains).

\section{Histricostoma mitovi sp. $\mathrm{n}$.}

(Figs. 4-10)

Material examined. Holotype ${ }^{\star}(\mathrm{ZMMU})$ and paratypes $10^{\Uparrow}$ (RCNS), 1 우 (ZMMU), TURKEY [T-12] Bursa, İnegöl, Great Oylat Cave, $39^{\circ} 56.601^{\prime} \mathrm{N} 29^{\circ} 35.492^{\prime} \mathrm{E}, 519 \mathrm{~m}$, 3.06.2009 Yu. M. Marusik.

Etymology. The species is being named in honor of the European specialist on Opiliones - Dr. Plamen Mitov.

Diagnosis. The new species is closely related to $H$. caucasicum (Redikorzev 1936) and H. creticum (Roewer 1927), but differs by the following aspects: in H. mitovi sp. n.: with blunt tubercles on tergites similar to those in Mediostoma species, $H$. caucasicum and $H$. creticum have cylindrical tubules, with tips formed by pointed denticle groups. In $H$. mitovi sp. n. the glans of the penis have other structure, than in $H$. caucasicum and $H$. creticum. In $H$. caucasicum the femora and patella of the pedipalp are thinner and longer, than in $H$. mitovi sp. n. In H. creticum the retrolateral side of the cheliceral segment I with numerous small black denticles, in $H$. mitovi sp. n. such denticles are absent.

Description. Male (holotype). Body 1.4 long, 0.9 wide; 


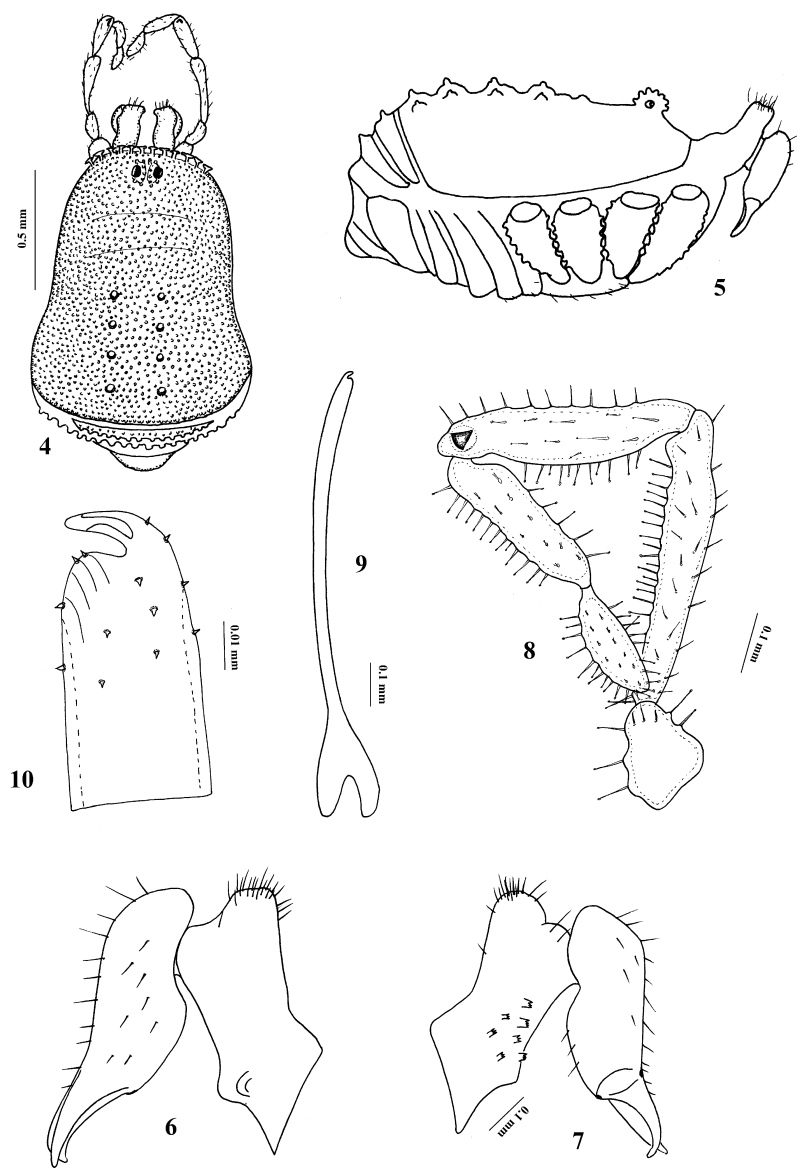

Figs. 4-10. Histricostoma mitovi sp. n., male holotype (Nursa, Inegöl, Great Oylat Cave). 4. Body, dorsal view; 5. Same, lateral view; 6. Right chelicera, prolateral view; 7. Same, retrolateral view; 8. Right pedipalp, prolateral view; 9. Penis, overall view; 10. Glans of penis, lateral view.

quadrangular with rounded angles, slightly widened posteriorly, with four pairs of small blunt denticles. Whole body surface granulated, dorsal outline of the body with bifid denticles. Anterior edge of the carapace with 12-15 " $T$ "-shaped denticles. Carapace and coxae outlines with the same denticles. Body and chelicerae dark-brown. Eye mound rounded, low, covered with granules. Legs relatively long, especially II and IV. Femora I and III thickened. Leg pseudoarticulations: I $-1-1$, II $-6-5$, III $-2-2$, IV $-3-4$. Lengths of palp and leg segments as in Table 1.

Distal segment of chelicerae with setae, basal segment covered with rows of denticles retrolaterally. Distal segment without a low apophysis, small hollow are on top surrounded by long setae. Cheliceral lengths: basal segment 0.43 , distal segment 0.50 . Pedipalps dark-brown, covered with pointed and capitate setae. Terminal part of patella with large recurved retrolateral hook-shaped tooth. Shape of penis typical for Histricostoma. Penis length 1.07.

Female. Similar to male, but differs by having a wider abdomen posteriorly, both the cheliceral gland and tooth on pedipalps are not present. Body 1.65 long, 1.10 wide. Cheliceral lengths: basal segment 0.4, distal 0.5. Leg pseudoarticulations: I - 1-1, II - ?-4, III - 2-2, IV - 4-4. Lengths of palp and leg segments as in Table 1.

Comparative material. Histricostoma creticum (Roewer 1927): 20, 1ㅇ, 2 juv, (SMF \#17081/5), Karpathos: oberhalb Mertonas, 17.04.1964, leg. J. Martens. Histricostoma caucasicum (Redikorzev 1936): 42 ${ }^{\top}$, 41우 (IZB 245), $15 \mathrm{~km}$ NNE from Zakataly, between I and II cordon, mountain slopes along right bank of the River Katekhchai, 800 m, 05.07.2004, leg. N. Snegovaya.

\section{Histricostoma gruberi $\mathrm{sp} . \mathrm{n}$}

(Figs. 11-17)

Material examined. Holotype ${ }^{\lambda}$ (ZMMU) and paratypes

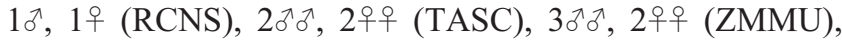
TURKEY [T-15] Aydın, Kuşadası, Dilek Peninsula Büyük Menderes Delta National Park, $37^{\circ} 41.735^{\prime} \mathrm{N} 27^{\circ} 09.802^{\prime} \mathrm{E}$, $106 \mathrm{~m}$, 7.06.2009 Yu. M. Marusik.

Etymology. The species has been named in honour of the famous European specialist in Opiliones - Dr. J. Gruber, who worked with the fauna of Turkey.

Diagnosis. The new species is most similar to $H$. cancasicum, but differs from it by having 5 pairs of tubercles (4 pairs in H. caucasicum). Eye mound in H. gruberi sp. $n$. is covered by large curved bifid tubercles whereas in $H$. caucasicum it is covered by small tubercles. In $H$. gruberi sp. $\mathrm{n}$. the glans of the penis have other structure, than in $H$. caucasicum. In H. caucasicum the femur and patella of pedipalp are longer and thinner, than these in $H$. gruberi sp. n.

Description. Male (holotype). Body 1.65 long, 1.0 wide. Body elongated-quadrangular with rounded edges. Abdominal part widened. Tergites $\mathrm{I}^{-} \mathrm{V}$ with five pairs of cylindrical tubercles slanting posteriorly, tips of tubercles with group of fine papilliform denticles. Eye mound elevated, rounded, covered with large denticles with tops that are recurved and somewhat hooked. Frontal edge of carapace with double/triple rows of blunt " $T$ " shaped tubercles. Dorsum and venter with granulations, venter with setae. Coxae bordered with "T"-shaped tubercles. Legs relatively short, I and III thickened, densely covered with granules. Leg pseudoarticulations: I $-1-1$, II $-8-6$, III $-2-2$, IV $-4-$ 5. Lengths of palp and leg segments as in Table 2 .

Chelicera dark-brown. Distal segment covered with setae. Basal segment with wide appendage, having a small deepening, densely covered with long setae. Basal segment dorsally and ventrally densely covered with group (brushlike) of denticles. Cheliceral lengths: basal segment 0.57, distal 0.57. Pedipalps light-brown, covered with pointed and capitate setae. Patella retrolaterally with triangular hook; tip of which recurved. Penis 1.29 long.

Female. Similar to male, but differs by wider body and absence of cheliceral modifications and gland. Body (paratype) 1.9 long, 1.25 wide. Basal segment of chelicera 0.4 long, distal -0.65 long. Length of palp and leg segments as in Table 2 . 
Table 1. Lengths of palp and leg segments of Histricostoma mitovi sp. n.

\begin{tabular}{|c|c|c|c|c|c|c|c|c|c|c|c|c|}
\hline & \multicolumn{6}{|c|}{ Male } & \multicolumn{6}{|c|}{ Female } \\
\hline & $\mathrm{Fe}$ & $\mathrm{Pa}$ & $\mathrm{Ti}$ & $\mathrm{Mt}$ & $\mathrm{Ta}$ & Total & $\mathrm{Fe}$ & $\mathrm{Pa}$ & $\mathrm{Ti}$ & $\mathrm{Mt}$ & $\mathrm{Ta}$ & Total \\
\hline Palp & 0.6 & 0.5 & 0.4 & - & 0.25 & 1.75 & 0.6 & 0.5 & 0.4 & - & 0.25 & 1.75 \\
\hline Leg I & 0.63 & 0.25 & 0.43 & 0.36 & 0.58 & 2.25 & 1.05 & 0.35 & 0.85 & 1.5 & 1.15 & 4.9 \\
\hline Leg II & 1.05 & 0.3 & 0.75 & 1.25 & 1.15 & 4.5 & 0.7 & 0.28 & 0.5 & 0.75 & 0.65 & 2.88 \\
\hline Leg III & 0.63 & 0.28 & 0.45 & 0.75 & 0.5 & 2.61 & 1.0 & 0.25 & 0.65 & 1.25 & 0.7 & 3.85 \\
\hline Leg IV & 0.88 & 0.25 & 0.55 & 1.13 & 0.75 & 3.56 & 0.65 & 0.28 & 0.45 & 0.7 & 0.7 & 2.78 \\
\hline
\end{tabular}

Table 2. Lengths of palp and leg segments of Histricostoma gruberi sp. n.

\begin{tabular}{ccccccccccccc}
\hline \multicolumn{19}{c}{ Male } & \multicolumn{9}{c}{ Female } \\
\hline & $\mathrm{Fe}$ & $\mathrm{Pa}$ & $\mathrm{Ti}$ & $\mathrm{Mt}$ & $\mathrm{Ta}$ & $\mathrm{Total}$ & $\mathrm{Fe}$ & $\mathrm{Pa}$ & $\mathrm{Ti}$ & $\mathrm{Mt}$ & $\mathrm{Ta}$ & $\mathrm{T}$ Tal \\
\hline Palp & 0.71 & 0.57 & 0.42 & - & 0.28 & 1.98 & 0.63 & 0.63 & 0.45 & - & 0.35 & 2.06 \\
Leg I & 1.0 & 0.4 & 0.65 & 1.3 & 0.9 & 4.25 & 1.0 & 0.35 & 0.65 & 1.2 & 1.0 & 4.2 \\
Leg II & 1.9 & 0.7 & 0.8 & 2.8 & 2.0 & 8.2 & 1.75 & 0.4 & 1.25 & 2.63 & 1.63 & 7.66 \\
Leg III & 1.1 & 0.53 & 0.65 & 1.4 & 0.9 & 4.58 & 1.13 & 0.35 & 0.65 & 1.38 & 0.88 & 4.39 \\
Leg IV & 1.8 & 0.38 & 0.95 & 2.05 & 1.3 & 6.48 & 1.75 & 0.38 & 0.88 & 2.0 & 1.15 & 6.16 \\
\hline
\end{tabular}

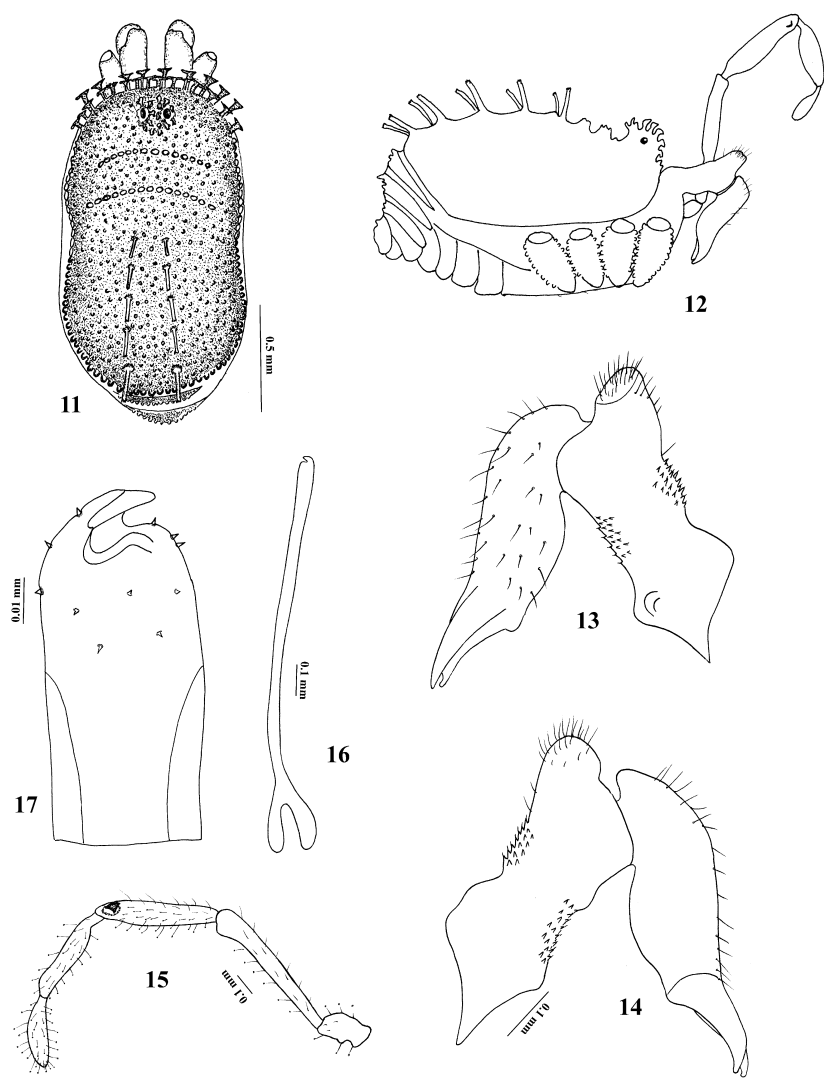

Figs. 11-17. Histricostoma gruberi sp. n., male holotype (Aydın, Kuşadası, Dilek Peninsula Büyük Menderes Delta National Park). 11. Body, dorsal view; 12. Same, lateral view; 13. Right chelicera, prolateral view; 14. Same, retrolateral view; 15. Right pedipalp, prolateral view; 16. Penis, overall view; 17. Glans of penis, lateral view.

\section{Histricostoma creticum (Roewer 1927)}

(Figs. 18-25)

Nemastoma creticum Roewer 1927, p. 454, fig. 1.

Mitostoma creticum: Roewer 1951, p. 148; Roewer 1959, p. 38;

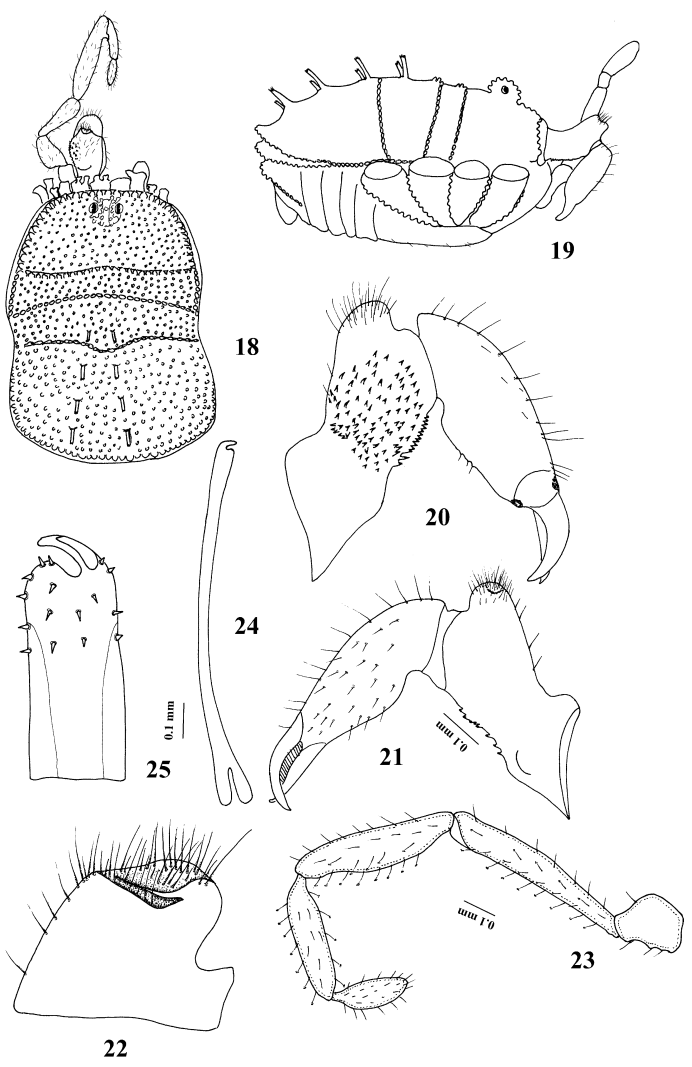

Figs. 18-25. Histricostoma creticum (Roewer 1927), male (Antalya, Alanya, Taşatan Plateau). 18. Body, dorsal view; 19. Same, lateral view; 20. Right chelicera, retrolateral view; 21. Same, prolateral view; 22. Cheliceral apophysis, prolateral view; 23. Right pedipalp, prolateral view; 24. Penis, overall view; 25. Glans of penis, lateral view.

Martens 1965, p. 67.

Histricostoma creticum: Gruber 1978, p. 568.

Material examined. $2 \delta^{\lambda}$, TURKEY [T-17a] Antalya, Alanya, Taşatan Plateau, 36²38.498'N 3204.089'E, 1167 m, 9.06.2009 Yu. M. Marusik.

Description. Male. Body 1.5 long, 1.1 wide. Body 
rectangular with rounded angles, from dark- to light-brown. Frontal edge of cephalothorax with bifid tubercles. Same tubercles situated on borders between merged tergites. Whole body covered with small grains. Tergites $\mathrm{II}^{-} \mathrm{V}$ with pairs of cylindrical denticles, tips of which bear group of papilla-like tubercles. Eye mound rounded, covered with quadrangular tubercles. Legs relatively short, femora of all legs with small black denticles, femora I spindle-shaped. Legs pseudoarticulations $-1-5-2-4$. Length of palps and legs segments as in Table 3.

Chelicera small, basal segment with small black denticles retrolaterally, densely covering all segment surfaces; with gland which prolaterally bears a small depression, densely covered with long setae. Distal segment covered with setae. Basal segment of chelicera $0.5 \mathrm{~mm}$ long, distal $0.55 \mathrm{~mm}$ long. Pedipalps short, covered with pointed and capitate setae. Patella top with large hook-like recurved. Penis 1.1 long.

\section{Histricostoma caucasicum (Redikorzev 1936)}

Nemastoma caucasicum Redikorzev 1936, p. 37, f. 7-8, 14; Roewer 1951, p. 135.

Histricostoma (Histricostoma) caucasicum: Staręga 1966, p. 394.

Histricostoma caucasicum: Staręga 1978, p. 201; Martens 2006, p. 192 , f. $21 \mathrm{a}-$ b, 26-27.

Material examined. 1우 (ZMMU), TURKEY [T-19] Artvin, Şavşat, Meydancık, Erikli Village, $41^{\circ} 24.302^{\prime} \mathrm{N} 42^{\circ}$ 17.809'E, 1141 m, 12.06.2009 Yu. M. Marusik; 1우 (TASC), TURKEY [T-20] Artvin, $9 \mathrm{~km} \mathrm{NNW}$ of Artvin, $41^{\circ}$ $15.642^{\prime} \mathrm{N} 41^{\circ} 46.365^{\prime} \mathrm{E}, 225 \mathrm{~m}, 13.06 .2009$ Yu. M. Marusik.

Comments. This species has a Caucasian range. It was described from Abkhazia. Later H. caucasium was reported from different parts of Georgia (Mcheidze 1964; Staręga 1966; Martens 2006), Azerbaijan (Snegovaya \& Chemeris 2005; Martens 2006), Armenia (Martens 2006) and Northern Caucasus (Krasnodar Province of Russia, Martens 2006). It was already reported by Martens (2006) from Turkey, from the same province (Artvin, Kackar Mountains).

Sclerosomatidae Simon 1879

Nelima pontica Charitonov 1941

Nelima pontica Charitonov 1941, p. 169, f. 5-6; Staręga 1966, p. 406, f. 22; Martens 1969, p. 412, f. 53-54, 57; Staręga 1978,

Table 3. Lengths of palp and leg segments of Histricostoma creticum (Roewer 1927) (male).

\begin{tabular}{ccccccc}
\hline & $\mathrm{Fe}$ & $\mathrm{Pa}$ & $\mathrm{Ti}$ & $\mathrm{Mt}$ & $\mathrm{Ta}$ & Total \\
\hline Palp & 0.6 & 0.5 & 0.35 & - & 0.25 & 1.7 \\
Leg I & 0.8 & 0.35 & 0.6 & 0.85 & 0.8 & 3.4 \\
Leg II & 1.25 & 0.4 & 1.1 & 1.9 & 1.45 & 6.1 \\
Leg III & 0.85 & 0.35 & 0.6 & 1.0 & 0.7 & 3.5 \\
Leg IV & 1.15 & 0.4 & 0.75 & 1.4 & 1.1 & 4.8 \\
\hline
\end{tabular}

p. 209; Chevrizov 1979, p. 16, f. 69-70; Mitov 1995, p. 64; Mitov 1997, p. 102, f. 9 b, d; Kunt \& Y1ldiz 2010, p. 11, 18, f. 11 .

Material examined. $10^{\text {}}, 1$ 우 (ZMMU), TURKEY [T-06] Kastamonu, Azdavay, $41^{\circ} 41.938^{\prime} \mathrm{N} 33^{\circ} 25.971^{\prime} \mathrm{E}, 975 \mathrm{~m}$, 30.05.2009 Yu. M. Marusik.

Comments. This species was described from Abkhazia and later it was reported from western Georgia (Mcheidze 1952, 1964; Staręga 1966), adjacent Russia (Sochi, Birshtein 1950), Bulgaria (Mitov 1995, 1997) and also from Turkey (Kunt \& Yıldiz 2010).

\section{Nelima sp.}

Material examined. 10 (RCNS), TURKEY [T-06] Kastamonu, Azdavay, $41^{\circ} 41.938^{\prime} \mathrm{N} 33^{\circ} 25.971^{\prime} \mathrm{E}, 975 \mathrm{~m}$, 30.05.2009 Yu. M. Marusik.

Comments. The single male we have has broken penis, therefore it cannot be correctly identified. Members of this genus are not known from Turkey, but in the adjacent Caucasus there are two species recorded: Nelima pontica and N. doriae (Canestrini 1872).

Phalangiidae Latreille 1802

Odiellus zecariensis Mcheidze 1952

Odiellus zecariensis Mcheidze 1952, p. 546, fig. 2; Mcheidze 1959, p. 112; Staręga 1966, p. 397, f. 12-14; Staręga 1978, p. 213; Chevrizov 1979, p. 18, f. 92-93; Chemeris \& Kovblyuk 2005 , p. 314 , f. $27-33$.

Material examined. 6 juv. (ZMMU), TURKEY [T-19] Artvin, Şavșat, Meydancık, Erikli Village, $41^{\circ} 24.302^{\prime} \mathrm{N} 42^{\circ}$ $17.809^{\prime} \mathrm{E}, 1141 \mathrm{~m}, 12.06 .2009$ Yu. M. Marusik; 5 juv. (ZMMU), [T-21/2-3] Artvin, Arhavi, $41^{\circ} 22.068^{\prime} \mathrm{N} 41^{\circ}$ 20.412'E, 225 m, 13.06.2009 Yu. M. Marusik.

Comments. While we have only juvenile specimens, we are sure of the identification because we have comparative material from Caucasus that contains both adult and juvenile specimens and it is a distinctive species. This species is new for the fauna of Turkey. It was described from centraleastern Georgia. Later it was found in Ajaria, Abkhazia, Stavropol and Krasnodar Provinces in Russia and also in Crimea (cf. Chemeris \& Kovblyuk 2005). Finding this species in Turkey is not a surprise, because it was known from the adjacent Ajaria. In general this species is restricted to the western Caucasus and Crimea.

\section{Odiellus lendli (Soerensen 1894)}

Odiellus lendli: Martens 1978, p. 343, f. 651-656, 642.

Odiellus bieniaszi (Kulczyński 1909): Staręga 1966, p. 395, f. 911.

Odiellus bieniaszi: Staręga 1978, p. 213; Snegovaya 1999, pp. 453-454, f. 14-18; Snegovaya 2002, p. 231. 
Odiellus lendli: Kurt \& Erman 2011, p. 1265-1270, f. 1-8.

Material examined. 8우 (ZMUT), Bithynia, HendekGümüşova, ca $40^{\circ} 50^{\prime} \mathrm{N} 30^{\circ} 45^{\prime} \mathrm{E}, 10.09 .1977$ P. T. Lehtinen.

Comments. This Opiliones is known all over Europe and east to the Caucasus. This is a widely distributed species, also reported from Turkey (Kurt \& Erman 2011).

\section{Lacinius sp.}

Material examined. 6 juv. (ZMMU), TURKEY [T-13] İzmir, Kemalpaşa, Vişneli, (Fetrek-2 Cave), $38^{\circ} 20.777^{\prime} \mathrm{N}$ $27^{\circ} 25.271^{\prime} \mathrm{E}, 311 \mathrm{~m}$, 5.06.2009 Yu. M. Marusik.

Comments. The juvenile specimens of this genus can not be identified to species level with certainty. Another species, L. ephippiatus (C. L. Koch 1885) was already reported from Turkey (Çorak et al. 2008) and another similar looking species, L. erinaceus Staręga 1966 is known from Abkhazia.

\section{Rilaena anatolica (Roewer 1956)}

(Figs. 26-36)

Platybunus anatolicus Roewer 1956, p. 303, f. 174-176. Rilaena anatolica: Staręga 1973, p. 143.

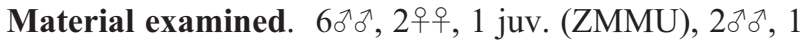
우 (RCNS), 2ðð, 1우 (TASC), TURKEY [T-06] Kastamonu, Azdavay, $41^{\circ} 41.938^{\prime} \mathrm{N} 33^{\circ} 25.971^{\prime} \mathrm{E}, 975$ m, 30.05.2009 Yu. M. Marusik.

Note. We redescribe this species in detail because it is otherwise only known by the original description.

Description. Male. Body 5.0 long, 3.2 wide; quadrangular, dark-brown, almost black, with numerous small light spots; covered with rows of denticles along margins of tergites. Groups of same sized denticles are in front of eye mound and along carapace edges. Supracheliceral lamellae with one denticle per side. Eye mound wide (1.0) with 1011 denticles around the top and outer sides of the ring. Legs short, pair I thickened. Femora of all legs with small denticles. Legs light-brown. Length of palp and leg segments as in Table 4.

Venter dark-brown, covered with setae; genital operculum lighter. Chelicerae large, dark-brown. Basal segment of chelicerae 2.0 long, distal - 2.3 long. Basal segment dorsally with some denticles. Distal segment dorsally with denticles and setae. Pedipalps dark-brown; femora

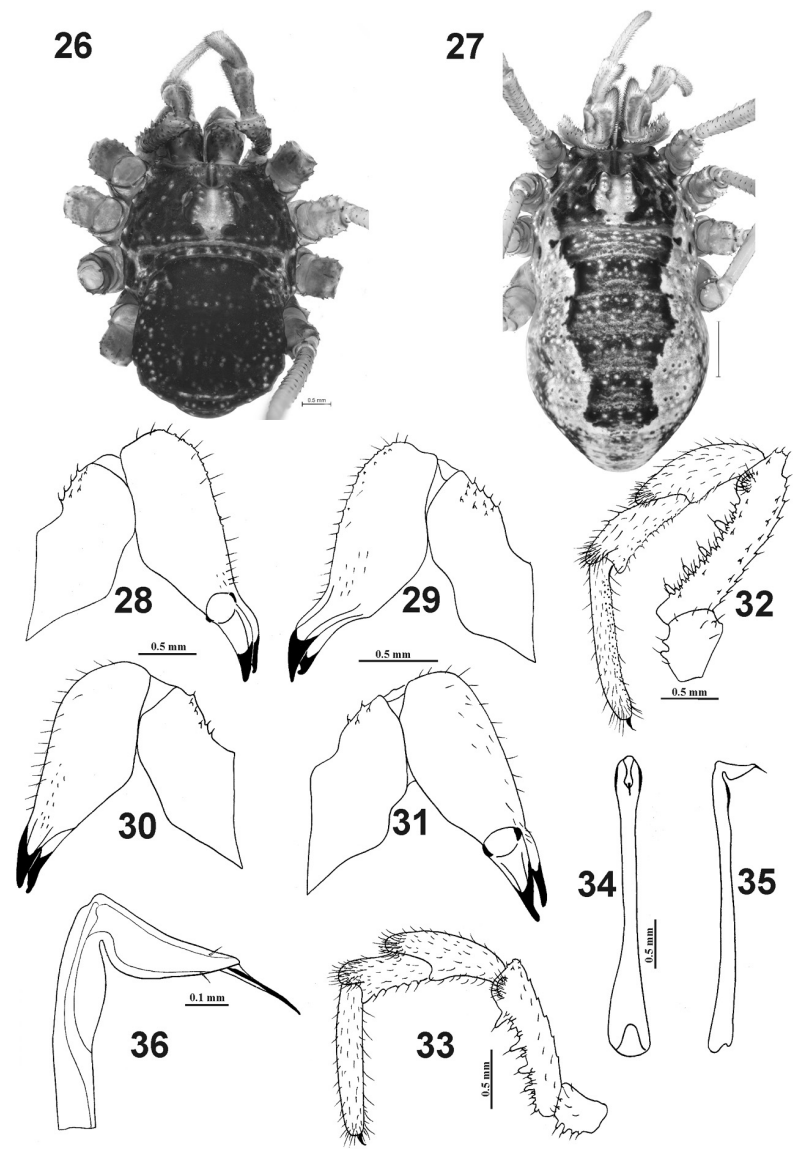

Figs. 26-36. Rilaena anatolica (Roewer 1956), male and female (Kastamonu, Azdavay). 26. Male body, dorsal view; 27. Female body, dorsal view; 28. Male right chelicera, retrolateral view; 29. Same, prolateral view; 30. Female right chelicera, prolateral view; 31. Same, retrolateral view; 32. Male right pedipalp, prolateral view; 33. Female right pedipalp, prolateral view; 34. Penis, ventral view; 35 . Same, lateral view; 36. Glans of penis, lateral view.

ventrally with small and much larger denticles, dorsally with denticles; patella covered with setae and with apophysis densely covered with setae Tibiae with small apophyses, also densely covered with setae, ventrally with small denticles. Tarsus with ventral granulations. Penis typical for Phalangiinae, truncus spoon-shaped with glans bent ventrally. Penis 3.1 long, glans 0.4 long and stylus 0.2 long.

Female. Similar to male, but differs by being longer and having a rounded body with dark-brown saddle mark. Femora I less thickened than in males. Body 6.2 long and

Table 4. Lengths of palp and leg segments of Rilaena anatolica (Roewer 1956).

\begin{tabular}{|c|c|c|c|c|c|c|c|c|c|c|c|c|}
\hline & \multicolumn{6}{|c|}{ Male } & \multicolumn{6}{|c|}{ Female } \\
\hline & $\mathrm{Fe}$ & $\mathrm{Pa}$ & $\mathrm{Ti}$ & $\mathrm{Mt}$ & $\mathrm{Ta}$ & Total & $\mathrm{Fe}$ & $\mathrm{Pa}$ & $\mathrm{Ti}$ & $\mathrm{Mt}$ & $\mathrm{Ta}$ & Total \\
\hline Palp & 1.75 & 1.25 & 1.1 & - & 1.6 & 5.7 & 1.3 & 1.2 & 1.0 & - & 1.5 & 5.0 \\
\hline Leg I & 3.1 & 1.1 & 2.8 & 2.1 & 3.9 & 13.0 & 2.0 & 1.0 & 1.8 & 2.1 & 4.2 & 11.1 \\
\hline Leg II & 4.5 & 1.5 & 4.0 & 4.5 & 7.6 & 22.1 & 4.0 & 1.75 & 3.7 & 4.1 & 7.5 & 21.05 \\
\hline Leg III & 3.3 & 1.2 & 2.75 & 3.5 & 4.7 & 15.45 & 2.8 & 1.0 & 2.25 & 3.5 & 4.3 & 13.85 \\
\hline Leg IV & 4.5 & 1.4 & 3.5 & 6.0 & 6.8 & 22.2 & 4.0 & 1.1 & 3.2 & 5.3 & 5.6 & 19.2 \\
\hline
\end{tabular}


3.1 wide. Females differ from males by the broader body, lighter coloration, less thickened leg I, thinner and almost not armed pedipalps. Basal segment of chelicera 1.5 long, distal -1.75 long. Lengths of palp and leg segments as in Table 4.

Comments. The species was described and known from the environs of only Ankara. Our new find extends the known range about $250 \mathrm{~km}$ to the north.

\section{Zachaeus crista (Brullé 1832)}

Zachaeus crista: Roewer 1923, p. 820, fig. 1023; Šilhavý 1965, p. 384, Tab III-V f. 1-4; Martens 1965, p. 71; Staręga 1976, p. 372, f. 71-73; Martens 1978, p. 301, f. 559, 567; Çorak \& Bayram 2007, p. 456.

Material examined. 1 juv. (ZMMU), TURKEY [T-09] Bursa, Uludağ National Park, $40^{\circ} 06.970^{\prime} \mathrm{N} 29^{\circ} 03.283^{\prime}$

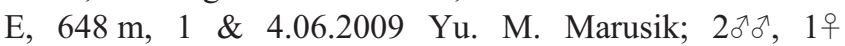
(RCNS), [T-10] Bursa, Nilufer, $40^{\circ} 07.466^{\prime} \mathrm{N} 28^{\circ} 42.105^{\prime} \mathrm{E}$,

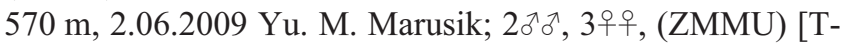
13] İzmir, Kemalpaşa, Vişneli, (Fetrek-2 Cave), $38^{\circ} 20.777^{\prime}$ $\mathrm{N} 27^{\circ} 25.271^{\prime} \mathrm{E}, 311 \mathrm{~m}, 5.06 .2009$ Yu. M. Marusik. 1우 (AMNH), İ zmir, Bergama (=Ancient Pergamon), 1821.05.1981 B. Malkin.

Comments. It is a widespread European species. In Turkey this species was first reported by Roewer (1956).

\section{Zachaeus anatolicus Kulczyński 1903}

Egaenus crista var. anatolicus Kulczyński 1903, p. 660.

Zachaeus anatolicus: Šilhavý 1955, p. 34, f. 1-5; Staręga 1976, p. 376 , f. $75-77$, Chevrizov 1979, p. 22, f. 119-121.

Metaphalangium kratochvili Šilhavý 1965, p. 394, Tab. II, f. 113.

Material examined. $10^{\curvearrowright}$ (RCNS), TURKEY [T-02] Ankara, between Kizllcahamam-Ankara roads, $40^{\circ} 21.133^{\prime} \mathrm{N}$ $32^{\circ} 40.811^{\prime} \mathrm{E}, 1000 \mathrm{~m}, 27.05 .2009$ Yu. M. Marusik.

Comments. This species has an eastern Mediterranean range. It was originally described from Turkey and later found in Caucasus, Greece, Bulgaria, and Yugoslavia. Record of this species from Crimea (cf. Chevrizov 1979) seems to refer to Z. simferopolensis Chemeris \& Kovblyuk 2005.

\section{Opilio insulae Roewer 1956}

(Figs. 37-43)

Opilio insulae Roewer 1956, p. 288, f. 128-130; Martens 1965, p. 69, f. 9-19; Staręga 2003, p. 97.

Opilio lindosiellus: Gruber 1963, p. 312.

Material examined. 10 (ZMMU), TURKEY [T-14] İzmir, Karaburun, $1 \mathrm{~km} \mathrm{~N}$ of Parlak Village, $38^{\circ} 36.016^{\prime} \mathrm{N}$

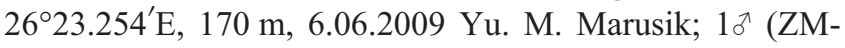

MU), $1 \sigma^{\Uparrow}$ (TASC), 10 (RCNS), [T-15] Aydın, Kuşadası, Dilek Peninsula, Buyuk Menderes Delta National Park, $37^{\circ}$ $41.735^{\prime} \mathrm{N} 27^{\circ} 09.802^{\prime} \mathrm{E}, 106 \mathrm{~m}, 7.06 .2009$ Yu. M. Marusik.

Note. We redescribe this species because it is relatively poorly known, and is a new species for Turkey.

Description. Male. Body 3.3 long, 2.1 wide; short, surface with numerous small light-brown and dark-brown spots. Whole body with rows of black-tipped tubercles. In front of eye mound with groups of black-tipped tubercles. Eye mound small, round, each ring with 4-5 denticles. Venter and coxae yellow, covered with setae. Chelicerae small, yellow; basal segment with several black-tipped tubercles and setae dorsally; distal segment with setae. Basal segment of chelicera 1.1 long, distal -1.25 long. Pedipalps yellow, femora with large spine-tipped tubercles and setae ventrally and with black-tipped tubercles and setae dorsally. Patellae with small denticles and setae dorsally, other parts with setae only; tibia with spines and setae; tarsus with setae and with fine denticles ventrally. Legs long, femora of all legs with transverse rows of denticles; femora I spindle-

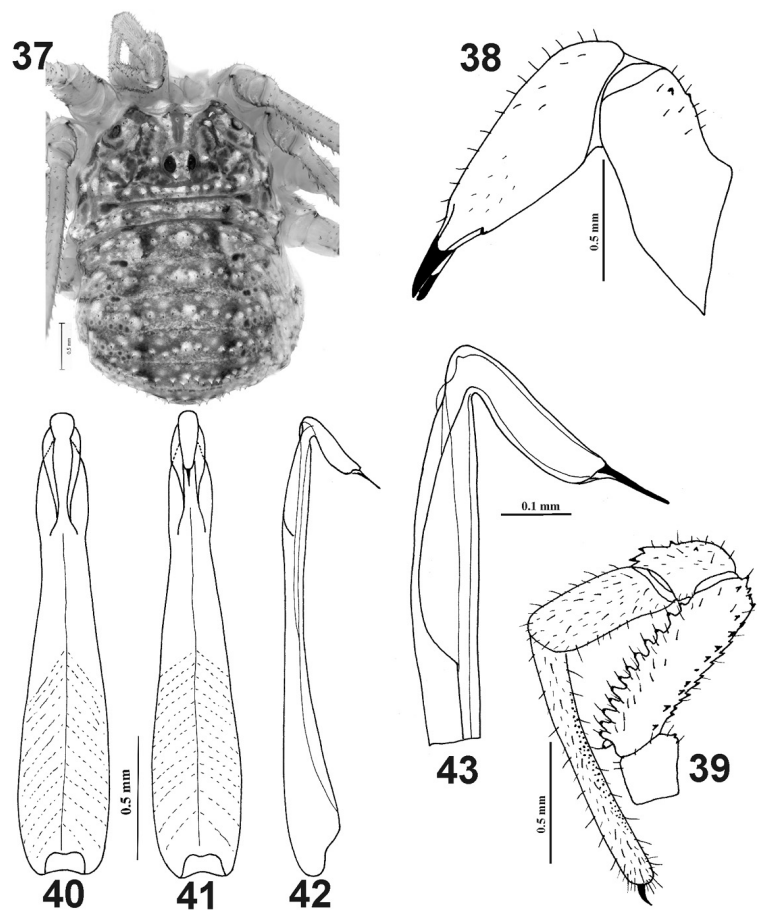

Figs. 37-43. Opilio insulae Roewer 1956, male (İzmir, Karaburun). 37. Body, dorsal view; 38. Right chelicera, prolateral view; 39. Right pedipalp, prolateral view; 40. Penis, dorsal view; 41. Seme, ventral view; 42. Same, lateral view; 43. Glans of penis, lateral view.

Table 5. Lengths of palp and leg segments of Opilio insulae Roewer 1956 (male).

\begin{tabular}{ccccccc}
\hline & $\mathrm{Fe}$ & $\mathrm{Pa}$ & $\mathrm{Ti}$ & $\mathrm{Mt}$ & $\mathrm{Ta}$ & Total \\
\hline Palp & 0.88 & 0.38 & 0.55 & - & 1.15 & 2.96 \\
Leg I & 2.8 & 0.8 & 2.5 & 2.7 & 4.7 & 13.5 \\
Leg II & 6.0 & 1.2 & 1.8 & 3.5 & 15.7 & 28.2 \\
Leg III & 3.1 & 0.9 & 2.5 & 3.0 & 5.3 & 14.8 \\
Leg IV & 4.6 & 1.0 & 3.6 & 4.2 & 7.8 & 21.2 \\
\hline
\end{tabular}


shaped; femora I and III pairs thickened. Lengths of palp and leg segments as in Table 5. Penis light coloured, widened in the base, tapering to the top, with small wings. Penis 1.9 long, glans 0.28 long, and stylus 0.1 long.

Comments. This species is new to the fauna of Turkey. It was described from Greece (Samos, and island close to Turkey). Besides Samos it was found on Chios, Ikaria, Krete, Karpathos, Lesbos, Rhodos and Symi (Martens 1965, 1966; Gruber 1978), so it was not a surprise to find this species on Aegean shore of Turkey a few kilometers from the type locality. Gruber (1978: 572) wrote about the occurrence of $O$. insulae in Izmir Province, but provided no details about the material or literature references.

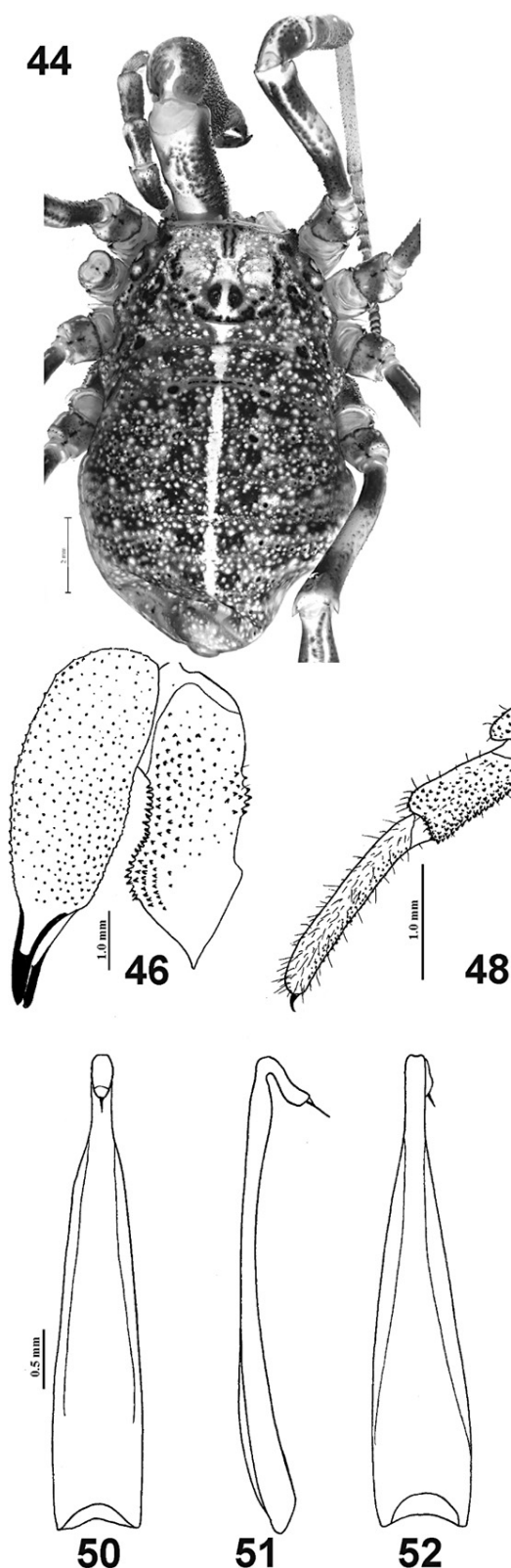

\section{Opilio parientinus (De Geer 1778)}

Material examined. $2 \circlearrowleft$ ภ $1000 \mathrm{~m}$, garage near garden, 13.11.1960, R. Walsh.

Comments. This is a widely distributed species previously reported from Turkey by Çorak \& Bayram (2007).

\section{Opilio sp.}

Material examined. $1 \delta, 1$ juv. (AMNH), TURKEY, Antalya, Arif (=Ancient Arikanda), 700 m, 10.05.1981 B. Malkin. 1ð, 3우우 (AMNH), Antalya, Kas, 5-7.05.1981 B.
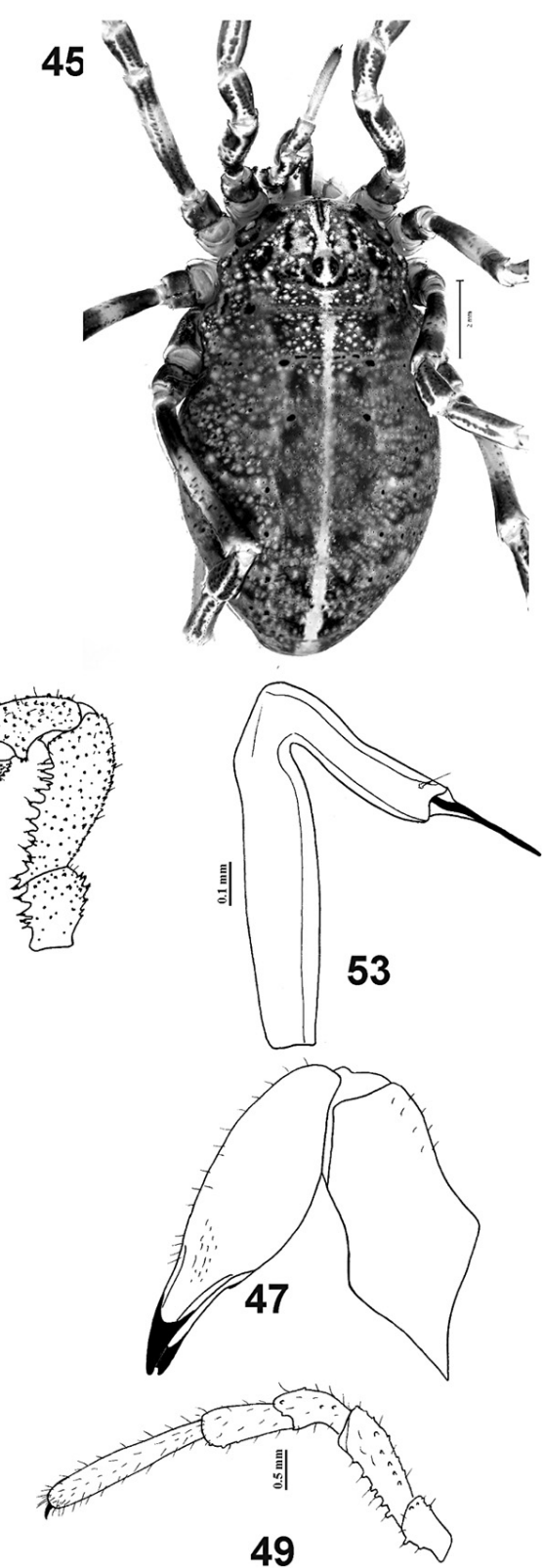

Figs. 44-53. Egaenus turcicus sp. n., male holotype and female paratype (Bursa, Nilüfer). 44. Male body, dorsal view; 45. Female body, dorsal view; 46. Male right chelicera, prolateral view; 47. Female right chelicera, prolateral view; 48. Male right pedipalp, prolateral view; 49. Female right pedipalp, prolateral view; 50. Penis, ventral view; 51. Same, lateral view; 52. Same, dorsal view; 53. Glans of penis, lateral view. 
Table 6. Lengths of palp and leg segments of Egaenus turcicus sp. n.

\begin{tabular}{|c|c|c|c|c|c|c|c|c|c|c|c|c|}
\hline & \multicolumn{6}{|c|}{ Male } & \multicolumn{6}{|c|}{ Female } \\
\hline & $\mathrm{Fe}$ & $\mathrm{Pa}$ & $\mathrm{Ti}$ & $\mathrm{Mt}$ & $\mathrm{Ta}$ & Total & $\mathrm{Fe}$ & $\mathrm{Pa}$ & $\mathrm{Ti}$ & $\mathrm{Mt}$ & $\mathrm{Ta}$ & Total \\
\hline Palp & 2.0 & 1.2 & 1.5 & - & 2.3 & 7.0 & 1.5 & 0.9 & 0.5 & - & 2.0 & 5.4 \\
\hline Leg I & 4.0 & 2.0 & 3.0 & 3.5 & 5.3 & 18.0 & 3.0 & 1.5 & 2.25 & 3.0 & 5.0 & 14.75 \\
\hline Leg II & 5.5 & 2.0 & 4.0 & 4.6 & 9.0 & 25.1 & 4.3 & 1.75 & 3.4 & 3.5 & 8.8 & 21.75 \\
\hline Leg III & 4.0 & 2.0 & 3.0 & 4.0 & 6.0 & 19.0 & 3.1 & 1.5 & 2.3 & 3.25 & 5.25 & 15.4 \\
\hline Leg IV & 5.4 & 2.0 & 3.8 & 6.2 & 8.2 & 25.6 & 4.75 & 2.0 & 3.2 & 5.7 & 7.1 & 22.75 \\
\hline
\end{tabular}

Malkin. 2 juv. (AMNH), Antalya, Ancient Myra, 8.05.1981

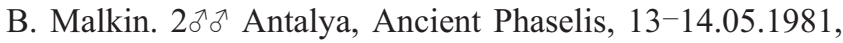
B. Malkin.

Comments. These represent a new record for Turkey and possibly a new species. Further study is needed. Maybe this is $O$. validus Roewer, 1959; which has not been recollected since the original collection from an unspecified locality in Turkey.

\section{Egaenus turcicus sp. n.} (Figs. 44-53)

Material examined. Holotype ${ }^{\lambda}(\mathrm{ZMMU})$ and paratypes $10^{\lambda}$ (RCNS), 1 우 (ZMMU) TURKEY [T-10] Bursa, Nilufer, $40^{\circ} 07.466^{\prime} \mathrm{N} \quad 28^{\circ} 42.105^{\prime} \mathrm{E}, \quad 570 \mathrm{~m}, \quad 2.06 .2009$ Yu. M. Marusik.

Etymology. The species is named after its type locality - Turkey.

Diagnosis. The species is most similar to $E$. convexus and can be separated from it by the penis with widened base, tapering to the tip (parallel sides in E. convexus) and by elongated glans with almost parallel sides (oval in $E$. convexus). In E. turcicus sp. n. the denticles are evenly distributed in the frontal part of carapace, whereas in $E$. convexus these denticles are concentrated in front of the eye tubercle. E. convexus has a broken transversal band of light pigment, whereas in the new species it is continuous. The general colouration in E. convexus is dark-brown and light brown in E. turcicus sp. n.

Description. Male (holotype). Body 11.0 long, 5.5 wide; large, entire body covered with fine denticles. Anterior part of carapace in front of eye mound with large microgranules. Median light stripe runs from eye tubercle to posterior part of opisthosoma. Eye tubercle low, with light median stripe and with rows of microdenticles on each side. Body brown with numerous small and round light spots. Venter light-brown, covered with small setae. Legs short, femora I and III slightly thickened; brown with white longitudinal stripe. Lengths of palp and leg segments as in Table 6.

Chelicerae very large, dark-brown. Basal segment densely covered with large denticles ventrally and dorsally; whole distal segment covered with fine denticles. Basal segment of chelicera 4.6 long, distal -6.3 long. Pedipalps relatively large, dark-brown; femora ventrally with large spine-tipped tubercles, dorsally with black-tipped tubercles and laterally with small denticles; patella covered with small black-tipped tubercles; tibia ventrally densely covered with denticles, laterally with denticles; tarsus covered with setae and ventrally with fine denticles. Penis with wide base tapering to the glans. Glans banana-shaped with almost uniform width throughout. Length of penis 3.8, glans 0.5, stylus 0.25 .

Female. Body 11.4 long, 5.2 wide. Basal segment of chelicera 2.5 long, distal - 3.0 long. Legs light-brown. Lengths of palp and leg segments as in Table 6. Female differs from male by the larger size of the body, smaller chelicerae andpedipalps; as well as less armed with denticles. Legs smoother than in males.

Comparative material. Egaenus convexus C. L. Koch 1835, $10^{\Uparrow}$ (RCNS), Serbia, Kragujevac, Šumarica, 10.05.1981, I. Karaman.

\section{Comments}

Before this study a total of 64 species and subspecies of Opiliones were known from Turkey (Kurt et al. 2010). Adding the species new to science and new records for the fauna of the country, the total number for the country is now 72 species. Species diversity in the country is rather high in comparison to adjacent countries. About 55 species are known in Bulgaria, 40-45 species have been reported from Azerbaijan. Among neighboring countries only Greece has more species (about 75). Taking into account the large size of Turkey and diversity in landscapes, it is easy to suggest that true species richness in Turkey could be $20-30$ species higher.

\section{Acknowledgments}

We thank P. Jäger (Frankfurt am Main, Germany - SMF), J. Martens (Mainz, Germany) for help with comparison with some types; I. Karaman (Novi Sad, Serbia) for supplying us with comparative material; and J. C. Cokendolpher (Lubbock, U.S.A.) for studying the specimens on loan to him from the AMNH (courtesy of L. Prendini). Special thanks also to K.B. Kunt for the invitation to YM to visit Turkey and for organizing the collecting trip. S. Koponen (Turku, Finland) helped with literature and arranged the stay of YM in Turku.

\section{References}

Bayram, A. \& Çorak, İ. 2007. A new record for the harvest spider fauna of Turkey: Dicranolasma giljarovi Šilhavý, 1966 (Opilionida, Dicranolasmatidae). Turk. J. Zool., 31: 9-12.

Bayram, A., Çorak, İ., Danışman, T., Sancak, Z. \& Yiğit, N. 2010 Checklist of harvestmen of Turkey (Arachnida: Opiliones). Mun. Ent. Zool., 5(2): 563-585.

Birshtein, J. A. 1950. Fauna of caves of the Western Caucasus. Zoologicheski Zhurnal, 29: 354-366 [in Russian]. 
Charitonov, D. E. 1941. New data about fauna of Arachnoidea in the caves of Abkhazia. [Novye dannye po faune Arachnoidea peščer Abhazii]. Trudy Instituta Zoologii Akademii Nauk Gruzinskoj SSR, Tbilisi, 4: 165-176 [in Russian].

Chemeris, A. N. \& Kovblyuk, M. M. 2005. A contribution to the knowledge of the harvestman fauna of the Crimea (Arachnida: Opiliones). Arthropoda Selecta, 1: 305-328.

Chevirizov, B. P. 1979. A brief key to the harvestmen (Opiliones) from the European part of the USSR. The fauna and ecology of Arachnida. Proc. Zool. Inst., 8: 4-27 [in Russian].

Çorak, İ. 2004. Systematics and bioecology of harvestmen collected from Anatolia (Arachnida: Opiliones). Msc Thesis, Kırıkale University, Graduate School of Natural and Applied Sciences, Department of Biology, Kirıkale, 84 pp.

Çorak, İ. \& Bayram, A. 2007. Harvestmen fauna of the Soğuksu National Park, Ankara (Arachnida: Opiliones). Munis Entomol. Zool., 2(2): 455-460.

Çorak, İ., Bayram, A., Karol, S., Danişman, T. S., Sancak, Z. \& Yiğit, N. 2008. A new record for the harvestmen fauna of Turkey: Lacinius ephippiatus (C. L. Koch, 1835) (Opiliones, Phalangiidae). Turk. J. Arachnol., 1(2): 114-117.

Giltay, L. 1933. Aracnides recueillis par M. D’Orchymont au cours de ses voyages aux Balkans et en Asie Mineure en 1929, 1930 et 1931. Bull. Mus. Royal d'Hist. Nat. Belg., 8(22): 1-40.

Gruber, J. 1963. Ergebnisse der von Dr. O. Paget und Dr. E. Kritscher auf Rhodos durchgefhrten zoologischen Exkursionen. VII. Scorpiones und Opiliones. Ann. Naturhistor. Mus. Wien, 66: 307-316.

Gruber, J. 1968. Ergebnisse zoologischer Sammelreisen in der Türkei: Calathocratus beieri, ein neuer Trogulidae aus Anatolien (Opiliones, Arachnida). Ann. Naturhistor. Mus. Wien, 72: 435-441.

Gruber, J. 1969. Weberknechte der Familien Sironidae und Trogulidae aus der Turkei. (Opiliones, Arachnida). (Ergebnisse der österreichisch-türkischen Anatolien-Expeditionen 9). Rev. Fac. Sci. Univ. d'Istanbul, (B), 34: 75-88.

Gruber, J. 1976. Ergebnisse zoologischer Sammelreisen in der Türkei: Zwei neue Nemastomatidenarten mit Stridulationsorganen, nebst Anmerkungen zur systematischen Gliederung der Familie (Opiliones, Arachnida). Ann. Naturhistor. Mus. Wien, 80: 781-801.

Gruber, J. 1978. Weberknechte (Opiliones, Arach.) von Inseln der Agais. Ann. Naturhistor. Mus. Wien, 81: 567-570.

Gruber, J. 1979. Ergebnisse zoologischer Sammelreisen in der Türkei. Uber Nemastomatiden-Arten aus der Verwandschaft von Pyza aus Südwestasien und Südosteuropa (Opiliones, Arachnida). Ann. Naturhistor. Mus. Wien, 82: 599-577.

Gruber, J. 1998. Beitrage zur Systematik der Gattung Dicranolasma (Arachnida: Opiliones, Dicranolasmatidae). I. Dicranolasma thracium Staręga und verwandte Formen aus Sudosteuropa und Sudwestasien. Ann. Naturhistor. Mus. Wien, B, 100: 489-537.

Kulczyński, W. 1903. Arachnoidea in Asia Minore et ad Constantinopolim a Dre. F. Werner collecta. Sitz.-ber. Akad. Wiss., Math.-naturw. Klasse (Vienna), 112: 627-680.

Kurt, K., Babaşoğlu, A., Seyyar, O., Demir, H. \& Topçu, A. 2008. New faunistic records for the Turkish harvestmen fauna (Arachnida: Opiliones). Munis Entomol. Zool., 3: 654-660.

Kurt, K., Demir, H., Seyyar, O. \& Topçu, A. 2008b. Some harvestmen records (Arachnida: Opiliones) from Nigde Province of Turkey. Serket, 11: 2-6.

Kurt, K. \& Köksal Eman, Ö., 2011. The first records of the genus Odiellus (Opiliones, Phalangiidae) in Turkey with some SEM studies on its morphology. Arch. Biol. Sci., Belgrade, 63(4): 12651271.

Kurt, K., Köksal Eman, Ö., Demir, H. \& Seyyar, O. 2010. The Turkish Harvestmen (Opiliones) with zoogeographical remarks. Serket, 12(2): 33-44.

Kunt, K. \& Y1ldiz, P. 2010. In YMBP (Invertebrates ) "Caves of the Yildiz Mountains and their fauna". Report prepared on behalf
AGRER-Agriconsulting-AGRIN by BUMAD (E. Çoraman, Y. Özakin, Y. Çelik, M. Döker, K. Kunt, and E. Özel) for the Ministry of Environment and Forestry, Ankara. Yildiz Mountains Biosphere Project Report Series No. 5: 1-65.

Martens, J. 1965. Über Südagaische Weberknecht der Inseln Karpathos, Rhodos und Kos. Senckenberg. Biol., 46: 61-79.

Martens, J. 1966. Zoologische Aufsammlugen auf Kreta. Ann. Naturhistor. Mus. Wien, 69: 347-362.

Martens, J. 1978. Spinnentiere, Arachnida: Weberknechte, Opiliones. Die Tierwelt Deutschlands. 64. G. Fischer Verlag, Jena, 464 pp.

Martens, J. 2006. Weberknechte aus dem Kaukasus (Arachnida, Opiliones, Nemastomatidae). Senckenberg. Biol., 86: 145-210.

Mcheidze, T. S. 1952. New species of harvestmen Opiliones from Georgia. Reports of AS Georgian SSR, Tbilisi, 13: 545-548 [in Georgian].

Mcheidze, T. S. 1959. Materials to study of spatial distribution of harvestmen in Georgian SSR. Papers of Tbilisi University, Tbilisi, 70, 109-117 [in Georgian].

Mcheidze, T. S. 1964. Opiliones. The animal world of Georgia. 2. Arthropoda. Tbilisi, 117-126 [in Georgian].

Mitov, P. 1995. New faunistic and chorological data about Opiliones (Arachnida) from Bulgaria. Ann. Univ. Sofia "St. Kliment Ohridski", Faculte de Biologie], (1-Zoology) 86-87, 63-65.

Mitov, P. 1997. Eine neue Nelima Roewer aus Bulgarien (Arachnida, Opiliones, Phalangiidae). Spixiana, Munchen, 20(2): 97-105.

Mitov, P. 2003. Rare and endemic harvestmen (Opiliones, Arachnida) species from the Balkan Peninsula. II. Three new for the Bulgarian fauna Opiliones (Arachnida) with zoogeographical notes. Linzer Biol. Beitr., Linz, 35: 273-288.

Nosek, A. 1905. Araneiden, Opilionen und Chernetiden. In: Penther, A., Zederbauer, E., Ergebnisse einer naturwissenschaftliche Reise zum Erdschais-Dagh (Kleinasien). Ann. Naturhistor. Mus. Wien, 20: $114-154$.

Redikorzev, V. V. 1936. Materialy k faune Opiliones SSSR. Trudy Zool. Inst. AN SSSR, 3: 33-57 [in Russian].

Roewer, C. F. 1923. Die Weberknechte der Erde. Systematische Bearbeitung der bishe bekannten Opiliones. G. Fischer, Jena, 1116 pp.

Roewer, C. F. 1927. Zoologische Streifzuge in Attika, Morea und besonders auf der Insel Kreta. I. V. Scorpiones, Opiliones und Solifugae. Abh. Naturw. Ver. Bremen, 26(3): 425-460.

Roewer, C. F. 1940. Neue Assamiidae und Trogulidae. Weitere Weberknechte X. Veröff. Deuts. Kolon.- Übersee-Mus. Bremen, 3: 1-31.

Roewer, C. F. 1950. Über Ischyropsalididae und Trogulidae. Weitere Weberknechte XV. Senckenbergiana, 31: 11-56.

Roewer, C. F. 1951. Über Nemastomatiden. Weitere Weberknechte XVI. Senckenbergiana, 32(1/4): 95-153.

Roewer, C. F. 1956. Über Phalangiinae (Phalangiidae, Opiliones Palpatores). (Weitere Weberknechte XIX). Senckenberg. Biol., 3: 247-318.

Roewer, C. F. 1957. Über Oligolophinae, Caddoinae, Sclerosomatinae, Leiobuninae, Neopilioninae und Leptobuninae (Phalangiidae, Opiliones Palpatores). (Weitere Weberknechte XX). Senckenberg. Biol., 38: 323-358.

Roewer, C. F. 1959. Die Araneae, Solifuga und Opiliones der Sammlungen des Herrn Dr. K. Lindberg aus Griechenland, Creta, Anatolien, Iran und Indien. Göteborgs K. Vetensk.-o. Vitterh.Samh. Handl. Ser. B, 8(4): 1-47.

Roewer, C. F. 1962. Über einige mediterrane Arachniden. Fragm. Entomol., 4: 11-18.

Scönhofer, A. \& Martens, J. 2008. Revision of the genus Trogulus Latreille: the Trogulus coriziformis species-group of the western Mediterranean (Opiliones: Trogulidae). Inverteb. Syst., 22: 523554.

Šilhavý, V. 1955. Výsledky zoologické expedice Národniho musea v Praze do Turecka. Sborník Entomol. Odd. Nár. Musea Praze, 30: 
31-39.

Šilhavý, V. 1965. Die Weberknechte der Unterordnung Eupnoi aus Bulgarien; zugleich eine Revision Europaischer Gattungen der Unterfamilien Oligolophinae und Phalangiinae (Arachnoidea, Opilionidea). Ergebnisse der zoologischen Expedition des Tschechoslowakischen Akademie des Wissenschaften nach Bulgarien im Jahre 1957 (Teil V). Ceskoslovenská Spolecnost Entomol. [=Acta Entomol. Bohemoslovaca], Praha, 62(5): 369406.

Šilhavý, V. 1966. Neue Troguliden aus dem Kuban-Gebiet und dem Kaukasus (Arach., Opiliones). Senckenberg. Biol., Frankfurt, 47(2): 151-154.

Snegovaya, N. Y. 1999. Contribution to the Harvest Spider (Arachnida, Opiliones) Fauna of the Caucasus. Turk. J. Zool., Ankara, 23: 453-459.

Snegovaya, N. Y. 2002. The harvestmen (Arachnida, Opiliones) of Ismailly State Reserve. VI International Conference "Biodiversity of the Caucasus" Makhachkala, Russia, 230-231 [In Russian].

Snegovaya, N. Y. 2004. Preliminary notes on the harvestman fauna (Opiliones) of Azerbaijan. In: Logunov D. V. \& Penney D. (eds),
European Arachnology 2003: 307-318.

Snegovaya, N. Y. \& Chemeris, A. N. 2005. A contribution to the knowledge of the harvestman fauna of the Zakataly State Reserve, Azerbaijan (Arachnida: Opiliones). Arthropoda Selecta, 13: 263278.

Staręga, W. 1966. Beitrag zur Kenntnis der Weberknecht-Fauna (Opiliones) der Kaukasuslander. Ann. Zool., 23: 387-411.

Staręga, W. 1973. Beitrag zur Kenntnis der Weberknechte (Opiliones) des Nahen Ostens. Ann. Zool., Warsawa, 30: 129-153.

Staręga, W. 1976. Die Weberknechte (Opiliones, excl. Sironidae) Bulgariens. Ann. Zool., Warsawa, 33: 287-433.

Staręga, W. 1978. Katalog der Weberknechte (Opiliones) der Sowjet-Union. Fragm. Faun., Warsaw, 23: 197-241.

Staręga, W. 2003. On the identity and synonymies of some Asiatic Opilioninae (Opiliones: Phalangiidae). Acta Arachnol., 52: 91-102.

Yigit, N., Bayram, A., Çorak, I. \& Danișman, T. 2007. External morphology of the male harvestman Phalangium opilio (Arachnida: Opiliones). Ann. Entomol. Soc. Amer., 100: 574-581.

Received January 15, 2011 / Accepted August 7, 2012 